\title{
クリティカルパス解析による並行多重プロジェクトの工期調整方式
}

\author{
正員杉 原 弘章 (三萲電機株式会社 名古屋製作所)
}

\section{A Method of Execution Time Adjustment in Parallel Projects Based on Critical Path Analysis}

\author{
Hiroaki Sugihara, Member (Mitsubishi Electric Corporation)
}

\begin{abstract}
It becomes very important that the potential delays in the delivery dates are estimated as early as possible and the adjustments to the production periods are applied as little as possible only to the higher priority items in order to maximize the effectiveness. However, just like planning the most optimized schedules on the job shop production floors, quantitative decision making on load change actions has been a very difficult problem. Thus, in order to solve such problems, we have proposed CSM (Concurrent Scheduling Method) as a means to plan schedules. Under CSM, the optimum schedule is planned to maintain the delivery dates while solving resource conflicts. In this article, a new technique is proposed in order to adjust production periods of projects (to be called as concurrent projects, hereafter), which share resources and are processed concurrently by investigating the established critical paths while a function is added to CSM.
\end{abstract}

キーワード：クリティカルパス、多重PERT、ジョフショッフ、スケジューリング、工程管理

Keywords : critical path, multi-PERT, job shop, scheduling, production process schedule control

\section{1． まえがき}

製造業における製造現場では、現有リソースを極限状態で 使用しながら、少しでも多くの受注を納期までに完成させる ことが強く求められている。このような製造現場では受注対 応でオーダと称する製造命令が出される。現有リソースを極 限状態で使用してより多くのオーダを処理しようとする場 合、ややもするといくつかのオーダは納期遅延となってしま う。このため、納期遅延をできるだけ早い時期に予測し、で きうる限り最小限の工期調整を重点的に行い最大の効果を あげることが重要になる。ここで工期調整とは製作完了予定 日と納期との関係を調整することである。たとえばジョブシ ヨップの製造現場では、工期調整として、残業・休日出勤・ 一部外注化などの負荷対策、工程設計の見なおし、納期交涉 による納期変更などが行われるが、負荷対策が主体となる。 ところが、負荷対策を定量的に決定することは、ジョブショ ップの製造現場における最適な日程計画立案の困難さと同

様、非常にむつかしい問題であった。

現有リソースを極限状態で使用してもなお納期遅延が発
生するかどうかを予測するためには、最適な設備運用をめざ した日程計画の立案が前提となる。ところが、多くのジョブ ショップの製造現場のように複数種類の部品がいくつもの 工程を渡りながら加工され、最終的に製品として組立てられ るような場合は、製品の製造時における要素作業としてのジ ヨブの構成は複雑になる。このような場合は、日程計画立案 時にリソースの競合問題がとりわけ頻繁に発生し、計画立案 を困難にしていた(1)(2)。

そこで、このような問題を解決するため、日程計画立案の 手段として、我々はリソース競合問題を解決しながら納期順 守をめざした最適な日程計画を立案するCSM (Concurrent Scheduling Method) を提案した(3)。CSMは、オーダご とのジョブ構成、つまり必要な要素作業としてのジョブの工 程の種類、相互関係、工数などを確定し、すでに着手してい るオーダについては各々のジョフ構成上で進渉を把握する。 このように把握した個々のオーダのジョブ構成を多重化し て、時系列にそってリソースごとの日程計画を立案する。こ こでジョブ構成の多重化とはジョブ構成図を重ねあわせた 状態を想定し、ジョブ構成図間のリソース競合を考虑しなが 
ら全体として同じ 1 本の時間軸で処理が進む状態をいう。こ の多重化によりリソースの最適な運用をめざした日程計画 立案が容易に行えるようになるとともに、納期予測、負荷推 移予測なども可能になった。

しかしながら、納期遅延が予測される場合、最適な負荷対 策を見出せないという課題が残つた。いいかえると負荷対策 を見出す場合、CSMによる日程計画立案で得られた負荷グラ フなどをもとに、納期遅延の要因を推定し、負荷対策を試行 錯誤で探し出しているため無駄な負荷対策も含めてしまう ので、負荷対策の最適化が課題として残った。

この論文ではこの課題を解決するため、CSMに機能を追加 し、CSMで把握したクリティカルパスの究明により、リソー スを共用しながら並行して処理されるプロジェクト（以下、 並行多重プロジェクトと称す) の工期を調整する方式を提案 する。この方式によれば、より無駄の少ない負荷対策を得る ことが可能になる。本方式をジョブショップ生産の製造現場 の工期調整に適用し有効性を確認した。

本稿では、2 章で従来の工期調整方式とその課題について 述へ、3 章で工期調整方式を提案する。4 章でその評価につ い飞論じ、考察を行う。

\section{2. 工期調整における課題}

日程計画において納期遅延が予測される場合、計画段階で 工期調整を行い、日程計画上での納期遅延を解消しておかな ければならない。従来、プロジェクトの工期調整を行う方法 としては、たえばPERT(Program Evaluation and Review Technique) やTOC (Theory Of Constraints ) があった。 PERTでは工期調整はクリティカルパスに対して行われ る。クリティカルパスは、始点から終点まで連続して連なり、 プロジェクトの工期をさめるパスとして表される。このプロ ジェクト全体の工期を短縮する場合、クリティカルパス上の アクティビティに対し対策を行っていた。単一プロジェクト の場合、この手法は大きな偉力を発揮したが、複数のプロジ エクトがリソースを共用 (4)しながら処理されるときに発生 する競合に関する問題を扱う機能は含まれていなかった。ま た、複数プロジェクトにまたがるクリティカルパスに関して も同様に含まれていなかった。これはもともとPERTは単一 ブロジェクトの計画管理手法として生まれたためである。

クリティカルパスについては、その多様性に着目した研究 が報告されている(5)。ところがジョブショップの製造現場 での納期対策への適用という面からのアプローチではない ため、納期遅延を解消するための負荷対策の定量的な解析に ついての機能は含んでいなかった。

TOCではりソース競合問題を解決する方法が提案されて いて、TOC理論により納期短縮が可能であることが報告され ている(6)。すなわち、図1に示すようなクリティカルパス とボトルネックリソースを組合せたクリティカルチェーン がプロジェクト全体の納期順守の制約条件になるとしてい る。工期調整はこのクリティカルチェーンに対し行う。この 図において四角形はジョブを示し細い矢線はジョブの実行
順序を示している。競合するリソースを使うジョブ、たとえ ば、図 1 ではBで示されるジョブは同一時間帯に重ならない ようにずらしている。このため、クリティカルバスとはちが った線をひく必要がある。これをクリティカルチェーンと称 している。この方法では、ボトルネックリソースが単数でな かったり、クリティカルチェーンが日によって異なることも あるようなジョブショップの製造現場では適用が困難であ つた。また、日々変化の多いジョブショップの製造現場にお いて、計画で納期遅延が予測される場合、負荷対策の詳細に ついては対象とされていない。

このほか、多重プロジェクトの計画に関する全体的な解析 についての報告 (7)や、負荷計画とスケジューリングの統合 についての報告(8) などがある。これらはいずれもプロジェ クト計画に関する最適化技術の応用であるが、ジョブショッ プの製造現場における日程計画上での納期遅延予測時の負 荷対策は含まれない。

このように従来の手法は目的が異なるため、複数プロジェ クトがリソースを共用しながら並行して処理されるショブ ショップの製造現場における日程計画や負荷対策の解析に は適さないと考えられる。CSMはこのような日々変化の多い 製造現場において計画上納期遅延が予測される場合、計画管 理者が負荷グラフなどを見ながら試行錯誤ではあるが負荷 対策を検討しやすくするものである。

CSMではオーダをそれぞれひとつのプロジェクトとみな し、並行多重プロジェクトを対象として製造現場を管理する。 CSMはすべてのプロジェクトの納期順守をめざし、最適な設 備運用による日程計画を立案する。これにそって製造現場で は作業が進められる。したがって納期遅延が発生するかどう かは日程計画立案時に予測できる。納期暹延が予測される場 合、日程計画に含まれるクリティカルパスを調へ、、負荷対策 に結びつける。

ただし、従来、クリティカルパスは日程計画上の余裕日数 がなくなることにより検出していた。クリティカルバスは奏 際にはもっと早い時点に発生し、段階的に余裕日数が隇って ついには余裕日数がなくなる。したがってクリティカルパス のはじめの段階で検出できるなら調整可能期間全体にわた

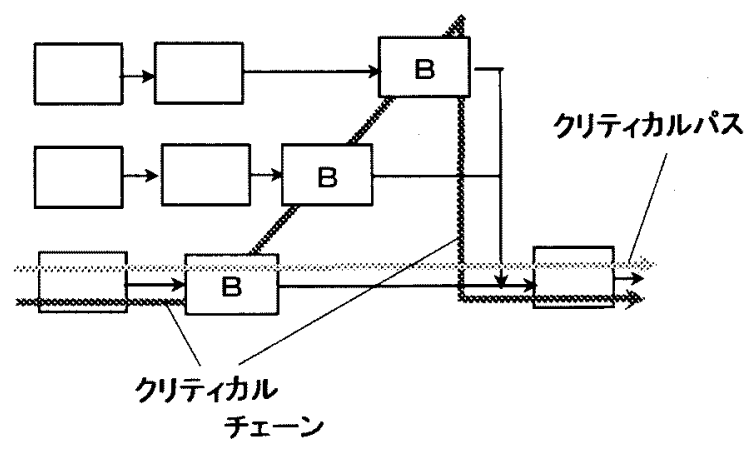

図 1 TOCのクリティカル・チェーン Fig. 1. Critical Chain in TOC 
って対策ができることになる。これができなかったため、ク リティカルパスは部分的にしか検出しないで負荷対策を行 っていたという問題があった。

\section{3. 並行多重プロジェクトの工期調整方式の提案}

CSMでは従来、クリティカルパスを余裕日数がなくなる夕 イミングから検出していた。本論文ではもっと早いタイミン グ、すなわちはじめにあった余裕日数が減少しはじめる夕イ ミングによりクリティカルパスを検出し、工期調整を行う期 間をさめる方法を提案する。りソースを共用しながら複数の オーダを好理する場合、オーダが湿みあってくると各オーダ の完成までの期間は長くなってしまう。これはジョブのリソ 一スでの競合が多くなり、待たされる時間がふえるからであ る。りリースの競合が発生するとき、姏理されるひとつの部 品以外の待たされる部品ははじめにあった余裕を隇少させ ながら処理される順番を待つが、これを余裕消費という。は じめに余裕のある部品でも余裕消費により次第に余裕がな くなり、余裕消費の累積值が当初の余裕を越えるとその部品 の属するオーダは納期遅延となる。

ここではまず並行多重プロジェクトのクリティカルパス について述べたあと、このクリティカルパスによる工期調整 について述べる。

<3.1>並行多重プロシェクトのクリティカルパス 一般的 に、クリティカルパスはプロジェクト全体を運命づけるパス であるといえる。

PERTでは、クリティカルパスはプロジェクトの工期（始 点から終点までの期間）を決めるパスと定義される。すなわ ち与えられる各ジョブ (アクティビティ) の所要工数とジョ ブ処理の相互関係を表すネットワーク図からクリティカル パスがきまり、工期がきまる。工期をいかにして短縮するか、 あるいは工期を計画どおりに実現するときどこを重点的に 管理するか、ということがPERTの関心事であり、クリティ カルパスは重要である。

一方、ジョプショップの製造現場では各プロジェクト（オ 一ダ）の工期は、与えられる納期からきめられ、遅れること は絶対許されない。そのため、CSMでは与えられた納期が守 れるか、もし守れないならなにが原因か、対策はなにかとい うことが重大な関心事となる。したがって、CSMにおけるク リティカルパスは「納期遅延を発生させるパス」とする。す なわち、すべてのオーダの納期を守るためにクリティカルな パスという意昧である。

CSMではクリティカルパスを次の3 種類に分類する。

・トラディショナルクリティカルパス

・主クリティカルパス

・従属クリティカルパス

これらを図2により説明する。詳細な説明に入る前に図 2

(a)ではこれらの説明に用いる用語の説明を行う。図にお いてひとつのオーダの処理手順をジョブボックスとオーダ 内コネクタであらわした図をプロセスチャートという。ここ でジョブボックスとは要素作業としてのショゴを示し、オー
ダ内コネクタとは部品毎の㚮理手順や組付け加工時の関係 を表す矢線である。オーダ内コネク夕で結ぶこれらの一連の パスをオーダ内パス (PWO：Path Within Order) と呼ぶ。 これらは工程設計の段階に決められる。図2（a）ではたと えば結合点 $\mathrm{P}_{01}$ から $\mathrm{P}_{09} に$ 続く細い実線がオーダ内パスである。 なお、プロセスチャート内でジョブボックスとジョブボック スが結ばれるオーダ内コネクタ上の点及び始点・終点を結合 点という。結合点には結合点番号がつけられる。

ジョブボックスからは他の種類の矢線、すなわちりソース 内コネク夕も連なっている。リソース内コネク夕は同じリソ 一スを用いて処理される他のジョブボックスと結ばれ、リソ 一スにおける処理の順序関係を示す。これは日程計画の段階 に決められる。リソース内コネクタで結ぶ場合は他のブロセ スチャートにまたがっても差し支えない。りソース内コネク タで結ぶこれらのパスをリソース内パス (PWR：Path Within Resource) と呼ぶ。このリソース内パスの例を結合 点 $\mathrm{P}_{06}$ から $\mathrm{P}_{07}$ に続く細い点線で示す。

プロセスチャート上では各工程は手順の名称をつける。各 工程における実際の処理は各工程のリソースで行われ、処理 待ちもリソース対応で発生する。このため競合に関する議論 はこれ以降はりソースについて行う。図2（b）には工程と リソースとの対応例を示す。この図によると、たとえば手順 としての土程 F はリソースF1で処理される。これらの準備 のもとに3種類のクリティカルパスを説明する。

図2（c）ではトラディショナルクリティカルパスを示す。 トラディショナルクリティカルパスはオーダの処理期間と して必要な最小限の期間すら与えられないときに現れ、単独 処理を想定しても納期までに処理できないパスを表す。オ一 ダ内パスに現われる。これは日程計画に入る前の工程設計の 段階で明確になる。最遅日程予余裕を算出したとき、余裕が マイナスのパスとして把握できる。ここで余裕とはオーダを 単独で処理する場合を想定して、納期からどれくらい早く完 成できるかをいう。トラディショナルクリティカルパスが発 生する場合は、処理期間が短かすぎるので計画立案するまで もなく納期遅延が発生するが、データ上は始点つまり第一工 程着手時にすでに余裕がマイナスとなる。負荷刘策などを加 えない限りこの状態の回復はありえないので、余裕のない状 態は終点まで連続する。図2（c）の例では $\mathrm{P}_{11}$ から $\mathrm{P}_{19}$ が トラディショナルクリティカルパスとなる。トラディショナ ルクリティカルパスが発生するとき、同じジョブ構成を PERT図であらわすとPERT図においてクリティカルパスと なる部分は少なくともブロセスチャート上ではトラディシ ヨナルクリティカルパスとなる。なぜなら最も所要期間が長 いパスを示しているからである。

トラディショナルクリティカルパスが発生している状態 で日程計画を立案すると、少なくともそのオーダは必ず納期 遲延となり他のオーダにも影響を与えるので、なんらかの処 置を行って解消してから他のオーダとともに日程計画を立 案する。

つぎに図2（d）に主りリティカルパスと従属りリティカ 

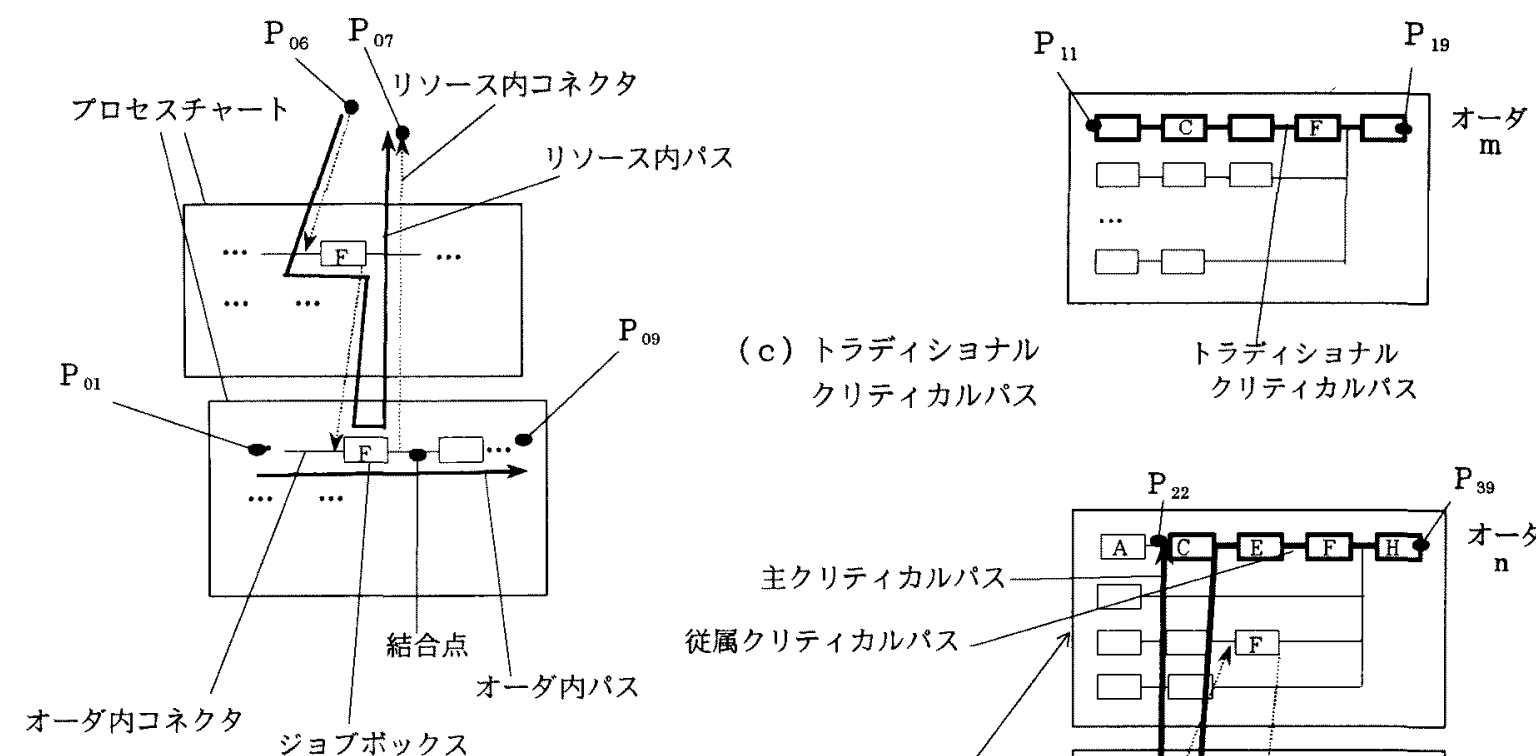

クリティカルパス

クリティカルパス

（a）用語の説明

\begin{tabular}{|c|c|}
\hline 工程 & リソース \\
\hline$A$ & $A 1$ \\
\hline$B$ & $B 1$ \\
\hline$C$ & C1 \\
\hline$F$ & $F 1$ \\
\hline$\cdots$ & $\cdots$ \\
\hline
\end{tabular}

(b) 工程/リソース 対応表 (d) 主クリティカルパスと 従属クリティカルパス

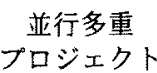

リソース内パスのー例 從属クリティカルパス
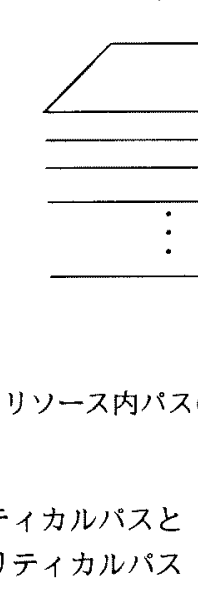$$
\text { 従属クリテイカルハス }
$$

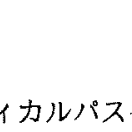

$\mathrm{P}_{22}$ 主クリティカルパス 22

$P^{P_{3}}$

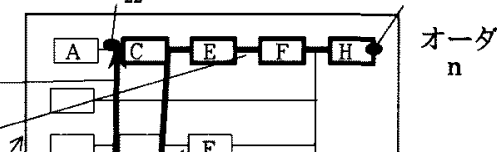

図 2 C SMのクリティカルパス

Fig.2. Critical Paths In CSM

ルパスを示し説明する。図 2 (d) の例では工程Cのリソー スC1でショゴの㵪滞が発生していることを示している。りり

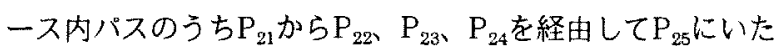
る太線で示される部分が主クリティカルパスである。

主クリティカルパスはリソース内パスのうち納期遅延の 直接の原因となる一連の部分である。リソースの競合でおき るジョブの渋滞により発生する。これは日程計画によって明 確になる。

従属クリティカルパスは主クリティカルパスでのジョブ の橴滞をきっかけとして発生するパスで、結果的には納期遅 延に導くオーダ内パスの一部である。主クリティカルパスに 属するジョブホッックスを起点として、これに続く終点までの
オーダ内パスが従属クリティカルパスとなる。従属クリティ カルバスも日程計画によって明確になる。

図2（d）の例では工程CのリソースC 1 におけるジョフ の沾滞により主クリティカルパスが発生していて、これに続 くオーダ内パスが従属クリティカルパスとなっている。従属 クリティカルパスはこの例ではオーダ $\mathrm{n}, \mathrm{n}+1, \mathrm{n}+3$ で 発生していて、オーダ $\mathrm{n}+2$ では発生していない。一例とし てオーダnのプロセスチャートにおいて、結合点 $\mathrm{P}_{22}$ から $\mathrm{P}_{39}$ に続くパスは従属クリティカルパスである。このように従属 クリティカルパスと主クリティカルパスは必ず関連しなが ら現われ、主クリティカルパスは他のオーダの従属クリティ カルパスにも連なることが多い。これらのオーダが主クリテ 
イカルパスを介して、たがいに完了日について影響を与え合 うことをあらわしている。

<3.2> クリティカルパス解析 ジョブショップの製造現 場ではクリティカルパスはオーダが納期遅延となる場合に 現れるが、納期遅延の原因はクリティカルパスを調べること で明確になる。ここでは、納期遅延が発生するとき、クリテ イカルパスの解析をもとに工期調整を行い、最終的には納期 遅延を解消した日程計画立案をめざす。この方式を図 $3 に$ す。図中、四角形で示されるブロックは各ステップで実施さ れることがらを表し、矢線は各ステップの実行順を示す。

図に掠いてクリティカルパス解析による工期調整は工程 設計の段階と日程計画の段階とにわかれる。工程設計の段階 ではトラディショナルクリティカルパスに基づいて処理し、 日程計画の段階では主クリティカルパスと従属クリティカ ルパスに基づいて処理する。

(1) トラディショナルクリティカルパスの解析 図3にお いて工程設計の段階ではトラディショナルクリティカルパ スの解析を行う。トラディショナルクリティカルパスは、ジ ヨフ構成を確定した後、他のオーダがない状態でそのオーダ だけを単独処理する場合を想定し、ジョブごとの余裕を算出 することにより検出できる。この場合、オーダ間やオーダ内 のリソースの競合は考虑しない。ジョブごとの余裕はジョブ ことの納期順守最荤開始時刻加算出される。納期順守最遅 開始洔刻とは、単独で処理される場合を想定したとき納期順 守できる最遅開始時刻である。また、同様に単独処理を想定 した場合、オーダの着手日からきまるジョブごとの最早の開 始日程を最早開始時刻という。これらを結合点についていう 場合は結合点時刻という。 オーダ $A$ の目標完成日を $P_{A}$ とすると、ジョブ間の結合
点 $i$ における最早結合点時刻 $t_{i}^{E}$ 、納期順守最達結合点時刻 $t_{i}^{N}$ は次式で表すことができる。ここで結合点 0 は始点、結

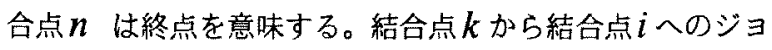
ブをジョブ $(k, i)$ とする。 $k<i$ である。オーダ $A$ のジ ヨフ構成に属するジョフの集合を $J A$ とすると、

$(k, i) \in J A \quad$ はショョプ $(k, i)$ がオーダAのジョブ構成に 属することを表す。また、 $D_{k i}$ はジョフ $(k, i)$ の所要時間 を表す。

$$
\begin{aligned}
& t_{0}^{E}= 0 \quad \cdots \cdots \cdots \cdots \cdots \cdots \cdots \\
& t_{i}^{E}=\max _{(k, i) \in J A}\left(t_{k}^{E}+D_{k i}\right) \quad \cdots \cdots \cdots \\
& \quad(i=1, \cdots n) \\
& t_{n}^{N}=P_{A} \quad \cdots \cdots \cdots \cdots \cdots \cdots \cdots \\
& t_{i}^{N}=\min _{(i, J) \in J A}\left(t_{j}^{N}+D_{i j}\right) \quad \cdots \cdots \cdots \\
&(i=n-1, \cdots 0)
\end{aligned}
$$

（1）式で結合点 0 の最早結合点時刻をさめたあと、（2） 式で結合点 1 について算出し、順次、結合点 $2 、 3 \cdots, n$ と 進めて全点の最早結合点時刻を算出することができる。同様 に結合点 $\mathrm{n}$ の納期順守最遅結合点時刻を（3）式できめ、順 次、結合点、 $n-1 、 n-2 、 \cdots 、 0$ と進めて全点について 算出することができる。

ジョブ $(i, j)$ の最早開始時刻 $E S_{i j}$ 、最早終了時刻 $E F_{i j}$ 、 納期順守最遅開始時刻 $N S_{i j}$ 、納期順守最遅終了時刻 $N F_{i j}$ は各々次のようになる。

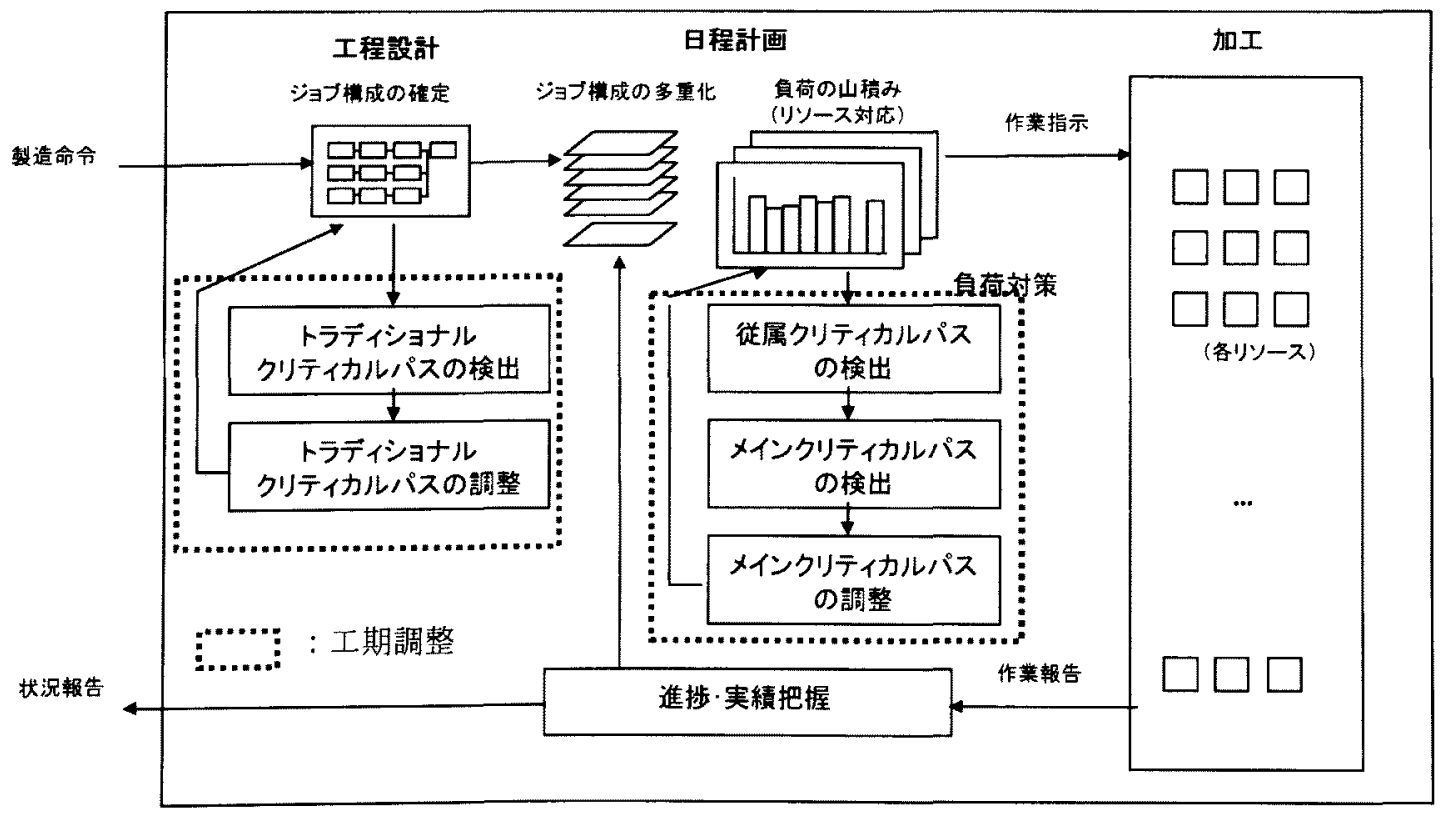

図 3 並行多重プロジェクトの工期調整方式

Fig. 3. A Method of Execution Time Adjustment in Parallel Projects 


$$
\begin{aligned}
& E S_{i j}=t_{i}^{E} \quad \ldots \\
& E F_{i j}=t_{i}^{E}+D_{i j} \\
& N S_{i j}=t_{j}^{N}-D_{i j} \\
& N F_{i j}=t_{j}^{N} \quad \ldots
\end{aligned}
$$

納期順守余裕時間 $D F_{i j}$ はつきのようになる。

$$
\begin{aligned}
D F_{i j} & =t_{j}^{N}-\left(t_{i}^{E}+D_{i j}\right) \\
& =N F_{i j}-E F_{i j} \quad .
\end{aligned}
$$

トラディショナルクリティカルパスが発生する場合、こ のパス上では、

$$
D F_{i j}<0
$$

となる。そして、先頭工程の最遅着手日時が計画開始日 時より前となる。つまり、各部品における始点（第一工 程）においてすでに余裕がないとき、その始点から終点 までトラディショナルクリティカルパスが続くことを 示している。トラディショナルクリティカルパスが発 生する場合、日程計画に組込む前の段階で消えるような 処置、たとえば、再度さらに工期を短縮するような工程 設計を試みるか、納期交涉または営業政策により納期を 変更するなど対策を行い、すべてのトラディショナルク リティカルパスを解消しなけれはならない。そして、日 程計画は対象となるすべてのオーダにおいてトラディ ショナルクリティカルパスがない状態で立案する。

(2) 主クリティカルパス、従属クリティカルバスの

解析 龱了において日程計画の段階では主ク リティカルパスと従属クリティカルパスに基づき解析 を行う。実際に負荷調整を行うのはおもに主クリティカルパ ス上であり、結果として負荷対策の効果が現れるのは従属ク リティカルパスである。

日程計画の段階までにトラディショナルクリティカルパ スはすべて解消させておくので、各部品はプロセスチャート 上の始点では余裕を有する。工程が進むにつれて混み合うリ ソースで処理されるジョブでは処理待ちが発生し、余裕は消 費される。納期遅延となるオーダでは余裕消費ジョブから納 期を越えて終点につながるバスはすべて従属クリティカル パスである。ただし、フリーフロートのあるパスではそれだ け差し引いて考虑される。ここでフリーフロートとはCSMで は組付け加工の手前で組付け他部品待ちとなるときの余裕 をいう。フリーフロートはPERTではジョブ構成が決まると ともに一意的に決まる。一方、CSMでは工程設計でジョフ構 成が決まっても他のオーダとのリソースの競合はきまらな いのでフリーフロートは決まらず、日程計画の立案ではじめ て決まる。計画を立て直す毎に值が変わる。たとえばリソー スの競合状態により組付け他部品が組付け工程にくる夕イ ミングがかかったときなどフリーフロートは変化する。

計画立案時、リソース $r$ におけるジョブ $(i, j)$ が主クリ ティカルパスに属するとする。このジョブ $(i, j)$ の競合

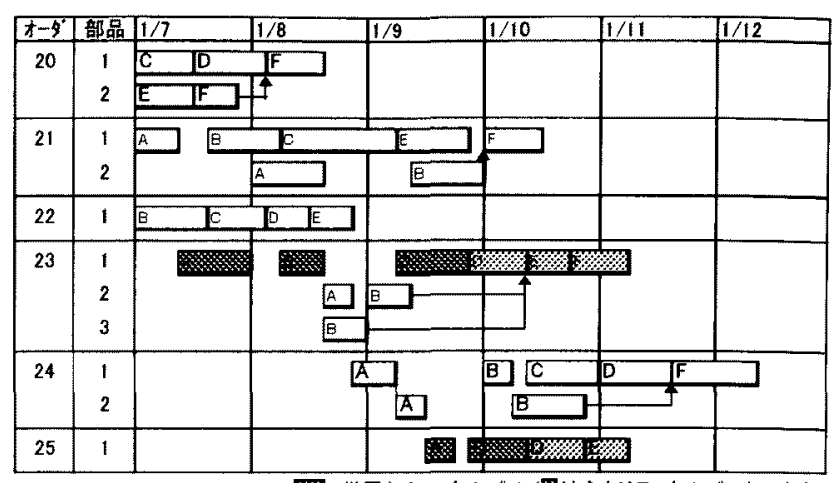

(a) オーダ内パスと従属クリティカルパス

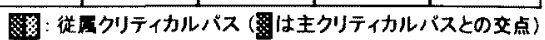

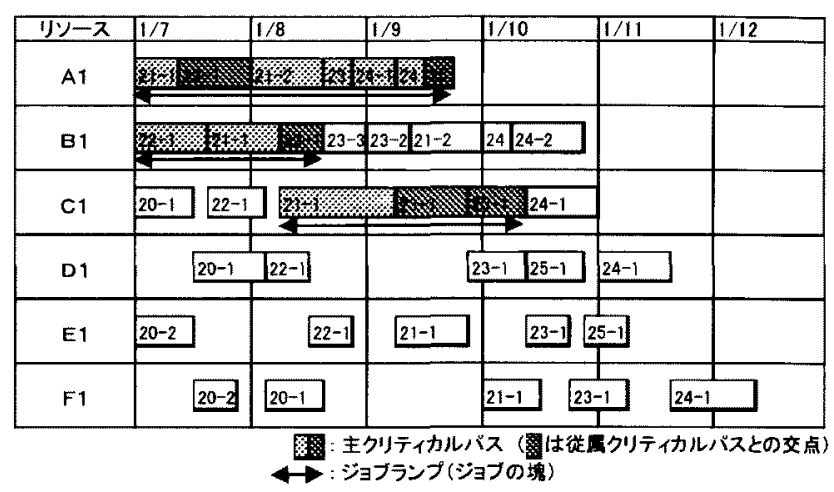

(b) リソース内パスと主クリティカルパス

図 4 主クリティカルパスにおけるジョブの塊の例

Fig. 4. A Job Lump On The Main Critical Path

による待ち時間を考慮すると、多重計画開始時刻 $M S_{i j}$ 、多 重計画終了時刻 $M F_{i j}$ は各々次のようになる。

$$
\begin{array}{r}
M S_{i j}=t_{i}^{E}+\sum_{r} W_{r} \quad \cdots \cdots \cdots \cdots \cdots \cdots \cdots(11) \\
M F_{i j}=t_{i}^{E}+\sum_{r} W_{r}+D_{i j} \quad \cdots \cdots \cdots \cdots \cdots(12) \\
\text { ここで、 } \quad \sum_{r} W_{r} \text { とは、これまでにジョブ }(i, j) \text { が属する }
\end{array}
$$

従属クリティカルパス上で交差する各リソースの主クリテ イカルパスにおいて待たされた時間の総和である。

結果として完成時期をきめる従属クリティカルパス上の 工程毎の余裕の変化をみると、何段階かにわけて減少するこ とが多いが、この式と一致する。何段階かにわけて減少する 場合、主クリティカルパスがいくつかのリソースで発生して いて着手前にあった余裕はこれらの主クリティカルパスと の交点ごとに次々と段階的に減少する。したがって納期遅れ が発生する場合、最終的には余裕は負になるものの、余裕が 負であるという条件だけでは従属クリティカルパスの全貌 は把握できない。

この一例を図 4 に示して説明する。図4（a）に抒いて納

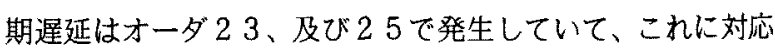
して従属クリティカルパスが発生していることを示してい 


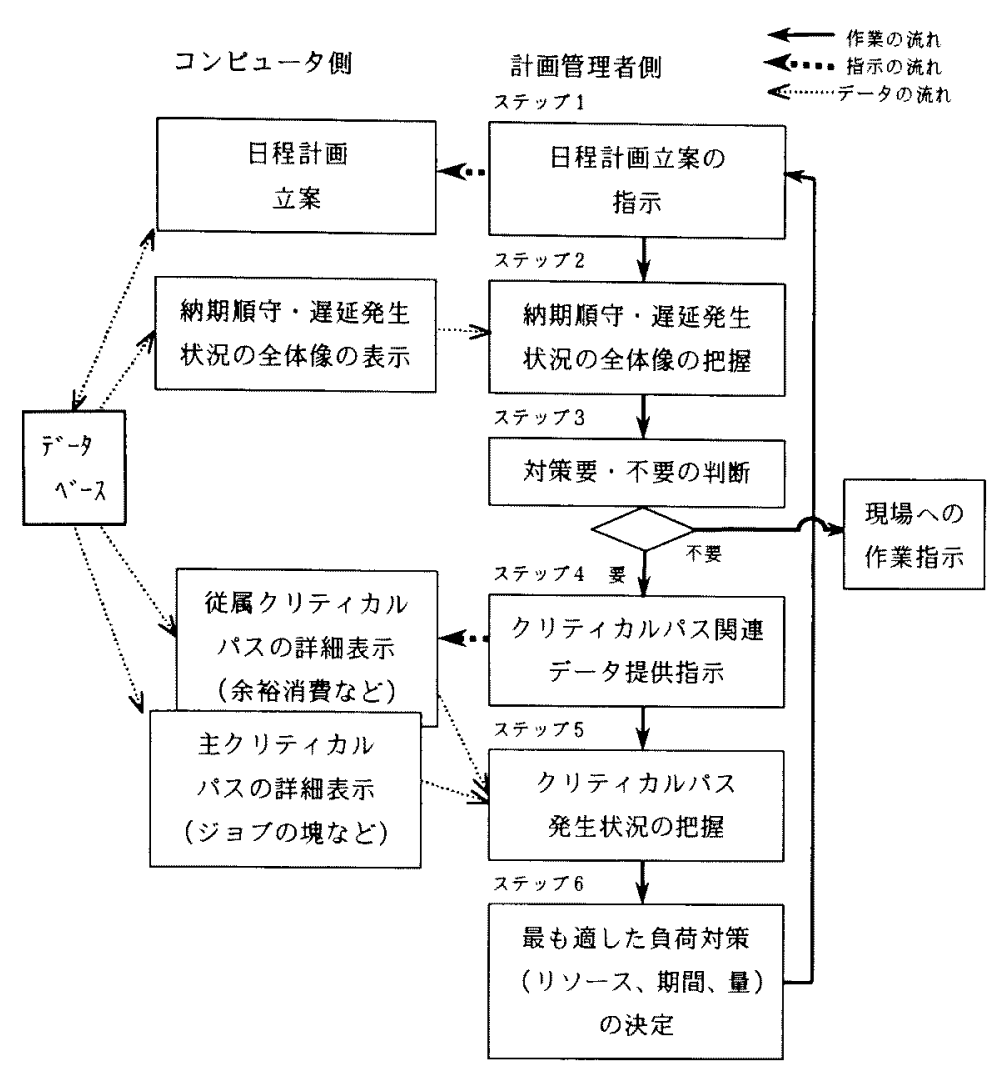

図5 日程計画を確定するまでのフロー

Fig.5. Flowchart for Decision of Manufacturing Instruction

る。図ではハッチした部分で示す。図 4 (b) では対応する リソースA 1、B 1、C1で主クリティカルパスが発生して いることを示している。罒では濃くハッチされた部分で 2 種 類のクリティカルパスは交わる。たとえばオーダ 230 部品 1 では対応する工程 A、B、Cで主クリティカルパ スと交わりジョブの処理待ちが発生しているが、段階的 に余裕が消費されていることを余裕及び余裕消費時間 数で示す。この例では時間で示しているが、日数などで 示すこともある。また、図4（b）に示すように、主ク リティカルパス上では時間軸にそって待ち行列が解消 されるまで、複数のジョブが連なる。これをジョブの塊 と称する。

$<3.3>$ 負荷対策へのクリティカルパス解析の応用 納期遅延が発生する場合、クリティカルパス解析を負 荷対策へ活用する。これにより状況の全体像を把握し、 必要に応じて負荷対策をきめる。この場合、大半はコン ピュータだけでは負荷対策の解はきまらない。解はいく つかあり、選択が必要になるからである。解がいくつも 存在するような場合、計画管理者の意思を反映しながら、 より適した解を選び出す作業が重要である。このとき意
思を反映しやすいようにコンビュー夕側では 状況を明確に示すとともに、選択肢を用意す る。計画管理者は種々の要因を考虑しながら 意思決定したあと、選択肢の中から解を選び 出し、コンピュー夕側でその選択肢にあわせ 結果を調べ示すという手順を繰り返し負荷対 策をさめる。

この場合の作業の流れを図 5 に示す。図に おいて、ステップ1で日程計画立案を指示し たあと、ステップ2でこの結果に基ついてま す、納期順守・遅延発生状況の全体像を把握 する。ステップ 3 では納期遅延の有無から負 荷対策の要・不要を判断する。

納期遅延が発生していて負荷対策が必要と 判断した場合は、ステップ4でコンピュータ にクリティカルパス関連のデータ提供を指示 する。コンピュータは従属クリティカルパス や主クリティカルパスについての詳細を表示 する。具体的には従属クリティカルパス上で の余裕消費分布や主クリティカルパスのジョ ブの塊などについて表示する。ステップ5で コンピュータの提供するこれらの情報に基づ き、クリティカルパスの発生状況を把握する。 発生状況の全体像を把握した上でステップ 6 では負荷対策についての意思を決定する。具 体的に負荷対策とは、リソースをきめ、対策 を行う期間と量をきめ、能力工数を增加させ ることである。

能力工数の調整で納期遅延を解消しようと する場合、あるリソースでの対策は全体的な 競合状態を変化させる。そのため、期間と量をきめて対策を 実施しても予想どおりの結果を得られないこともある。また、

\section{表 1 納期順守最遅日程の例}

Table 1. Example of the Latest schedule to Maintain the Delivery Dates

【オーダ:2-314】

部 品: 100

\begin{tabular}{|c|c|c|c|c|c|}
\hline \multirow{3}{*}{ No } & \multirow{3}{*}{ 工程 } & \multirow{2}{*}{\multicolumn{2}{|c|}{ 所要工数 }} & \multicolumn{2}{|c|}{ 納期順守最遅開始日程 } \\
\hline & & & & \multirow{2}{*}{$\begin{array}{c}\text { 納期: } 2 \text { 月 } 24 \text { 日 } \\
\text { の場合 }\end{array}$} & \multirow{2}{*}{$\begin{array}{c}\text { 納期: } 3 \text { 月 } 2 \text { 日 } \\
\text { 小場合 }\end{array}$} \\
\hline & & 日 & 時間 & & \\
\hline 1 & A & & 5.0 & 2月10日 & 2月 15日 \\
\hline 2 & B & & 2.0 & 10 日 & 15 日 \\
\hline 3 & C & 3 & & 14日 & 16日 \\
\hline 4 & $\mathrm{D}$ & & 4.0 & $17 日$ & $21 日$ \\
\hline 5 & $E$ & & 2.0 & 17日 & 21 日 \\
\hline 6 & F & & 4.0 & 17日 & 21日 \\
\hline 7 & $\mathrm{G}$ & & 3.0 & 18日 & 22日 \\
\hline$\cdots$ & .. & " & $\cdots$ & $\cdots$ & .. \\
\hline 20 & $Z$ & & 3.0 & 2月23日 & 3月 1 日 \\
\hline
\end{tabular}




\section{表 2 納期遅延日数の例}

Table 2. Examples of Delay Time in Derivery $\quad$ （b）各ケースの遅延日数

単位：日数

（a）各ケースの負荷対策

Z1
\begin{tabular}{|c|c|c|c|}
\hline 月日 & 单位:時間 \\
\hline 2月19日 & 0 & 8.0 & 4.0 \\
\hline 2月26日 & 0 & 8.0 & 0 \\
\hline
\end{tabular}

K1
\begin{tabular}{|c|c|c|c|}
\hline 月日 & ケース0 & ケース1 & ケース 2 \\
\hline 2 月19日 & 0 & 4.0 & 0 \\
\hline
\end{tabular}

D1

\begin{tabular}{|c|c|c|c|}
\hline 月日 & ケース0 & ケース1 & ケース2 \\
\hline 2月26日 & 0 & 4.0 & 0 \\
\hline
\end{tabular}

\begin{tabular}{|c|c|c|c|c|c|c|}
\hline \multirow[t]{2}{*}{ オーダ } & \multirow[t]{2}{*}{ 着手日 } & \multirow{2}{*}{$\begin{array}{l}\text { 完 } \\
\text { 指示日 }\end{array}$} & \multirow[t]{2}{*}{ 納 期 } & \multicolumn{3}{|c|}{ 遅 延 $\quad$ 日 数 } \\
\hline & & & & ケース0 & $5-x 1$ & ケース2 \\
\hline $2-211$ & 1月 7日 & 2月17日 & 2月18日 & -1 & -1 & -1 \\
\hline $2-212$ & 10 日 & 17 日 & 18 日 & -1 & -1 & -1 \\
\hline $2-213$ & 11日 & 18日 & $21 日$ & -1 & -1 & -1 \\
\hline $2-225$ & 12日 & 17 日 & 18日 & 0 & 0 & 0 \\
\hline $2-226$ & 18 日 & $22 日$ & 23 日 & -1 & -2 & -1 \\
\hline $2-227$ & 25 日 & 24 日 & 25 日 & -1 & -1 & -1 \\
\hline $2-228$ & 26 日 & 23 日 & 24日 & -1 & -1 & -1 \\
\hline $2-229$ & 24 日 & 29 日 & 3月1日 & -1 & -2 & -1 \\
\hline $2-230$ & 26日 & 29 日 & 1日 & -3 & -2 & -3 \\
\hline $2-231$ & 25 日 & 3月 1 日 & 2 日 & 0 & -1 & -1 \\
\hline $2-301$ & 2月 3 日 & 7日 & 8 日日 & +1 & -2 & 0 \\
\hline $2-302$ & 7 日 & 2日 & 3日 & 0 & 0 & 0 \\
\hline $2-303$ & 8日 & 7 日 & 8 日 & 0 & -3 & -1 \\
\hline $2-305$ & 8日 & 2 月 $25 日$ & 2 月 28 日 & 0 & -1 & 0 \\
\hline $2-306$ & 9日 & 3月10日 & 3月13日 & 0 & -2 & -1 \\
\hline $2-307$ & 10日 & 8日 & 9日 & +1 & -2 & 0 \\
\hline $2-308$ & 10日 & 14日 & 15日 & -1 & -1 & -1 \\
\hline $2-309$ & 10日 & 14日 & 15日 & 0 & -1 & -2 \\
\hline $2-312$ & 15 日 & 17日 & 21日 & -1 & -1 & -1 \\
\hline $2-313$ & 15日 & 21日 & 22 日 & -2 & -1 & -1 \\
\hline $2-314$ & 15日 & 1日 & 2 日 & 0 & 0 & 0 \\
\hline
\end{tabular}

対策が複数のリソースにわたる場合はこの影響はさらに大 きくなる。このため負荷対策を行い、結果をみて新たな結果 に対応してつぎの負荷対策を検討する、というようなことも 場合によっては必要になる。

負荷刘策をきめるにあたっては、図4に示した主クリティ カルパスのジョブの塊を考慮する。納期遅延の原因となるジ ヨブは必ず待ち行列に入っている。そのようなジョブの前に は他のジョブが隙間なく時間軸にそって並んでいる。これが ジョブの塊である。納期遅延を解消するためには、ジョブの 塊の起点や順序は変えないで問題のジョブの処理をもっと 時間軸上の前方に移動する必要がある。そのためには問題の ショョブひとつだけでなく、この部分の能力工数を増加させ問 題のジョブの前にある一連のジョブの塊全体を短期間に処 理し、前方へ移動する必要がある。問題のジョブをどの程度、 前へ移動するかをきめると、対策を行うべき期間と量が決ま る。

この負荷対策による競合状態の変化をみるため、再度 日程計画を立案し、必要に応じ同様の処理を繰返す。このよ うにすることで納期遅延が解消される日程計画に効率よく たどり着くことがでさる。

\section{4. 製造現場における実証と考察}

ここでは、ジョブショップの製造現場を刘象としてとりあ げ、立案された日程計画に含まれるクリティカルパスを把握 し、その負荷対策について実際のデータで工期調整を行う。

<4.1> 実証 すでに着手しているすべてのオーダが納期 に間にあう状態のとさ、2月14日に新たにオーダ2-314 を受注した場合について、表 1 で新規に受注したオーダのあ る部品における納期順守最迤日程の例を示すとともに、表 2
で処理対象となる全オーダの納期遅延日数の例を示し説明 する。新規オーダの納期は2月24日にならないか検討するよ う顧客から依頼があった。さっそく工程設計を行い表 $1 . に$ 示すように納期順守最遅日程を算出した。その結果、部品100 の第一工程の納期順守最遅着手日は2月10日 ですでに過去 の日付となり、トラディショナルクリティカルバスが発生す ることがわかった。工程設計をみなおしたが、工期をこれ以 上短縮できないうえ、負荷の混み具合から見て無理なことが 予想されるので、納期は3月2日以降にしてもらえないか顧客 に相談して3月2日ということで了承してもらえた。これでト ラディショナルクリティカルパスは解消できた。現場への完 了指示日は3月1日となる。そのかわり、すでに受注し着手し ている $2-307$ の納期を3月16日から3月9日に早め ることができないか打診があった。納期変更の場合は最遅日 程が変化するためこのオーダは工程設計の段階に戻る必要 がある。末着手ジョブのジョブ構成には変更がないものとし、 未着手ジョブについて最遅日程や余裕などを再計算した。再 計算結果によりこの時点で未着手先頭工程の余裕を調ベ、ト ラディショナルクリティカルパスが発生していないことを 確認した。つまり、未着手先頭工程の納期順守最㒓開始日と 当日日付とから考えると余裕があることは判明したが、他と の競合でどのようになるか日程計画を立案しないとわから ないので、一応検討すると回答した。この状態で日程計画を 立案した結果を表 2 .のケース0で示す。負荷対策はなにも 行っていないケース0の達延日数の欄をみると、 $2-301$ と2-307でプラスの遅延日数が示されている。これは納 期遅延が発生することを示している。そこで、負荷対策を二 つのケースについて行い、結果を比較する。

ケース 1 は、比較のため従来の方法で負荷対策を決める場 
合である。従来は負荷グラフから工程 $\mathrm{Z}, \mathrm{K}, \mathrm{D}$ のリソース で負荷が混んでいることを読み取り、これらのリソースで負 荷対策を行う場合を示す。つまり、表 $2 （ a ） に$ 示した時間 分、残業や休日出勤を行うとして計画をたてた。計画立案結 果を見ておさまりそうなのでこれで実行していた。

ケース 2 は、図 5 のフローにしたがって「負荷対策を行う のに最も適したリソース」を判断する場合を示す。ステップ 1 の日程計画で得られた結果（ケース0) からステップ2で 納期順守・納期遅延発生状況の全体像を把握する。ここでは 表 2 （b）から2つのオーダで納期遅延が発生していること

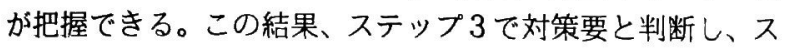
テップ4でクリティカルパス関連のデー夕提供を指示する。 ステップ 5 で提供されたデータにより余裕消費の分布を見 るとZ 1で極端に大きな余裕消費が発生していることをつ きとめ、ステップ6でZ1の主クリティカルパスに注目した。 そこで Z 1 のジョブの塊をみて、期間と短縮すべき量をきめ、 対応して残業、休日出勤など負荷対策をきめた結果、このよ うにして、リソース Z 1 でのわずか 4 時間分の残業で満足す ベき結果か得られた。

<4.2> 考察 クリティカルパスの解析により、工程と期 間、負荷超過量などが判断できるようになり、負荷対策がと りやすくなった。

例題により、主クリティカルパス、従属クリティカルパス、 トラディショナルクリティカルパスを示し、これらのクリテ イカルパスを解消する様子を示した.ここではまず、第一段 階でトラディショナルクリティカルパスを解消させた。その あと第二段階で日程計画を立案し、現れた主クリティカルパ ス、従属クリティカルパスを解消させた。このとき、人の意 思を反映させながら思いどおりの解を組立てていく感覚で 最終的には最小限の負荷対策を得ることができた。

\section{5.むすび}

ジョブショップ生産の製造現場において、日程計画を立 案して納期遅延が予测される場合、的をしほった負荷対策 を見つけ出す方法を提案した。ここでは納期遅延が発生す るときのクリティカルパスについてその特徵を述べた。そ して、クリティカルパスを調べることで負荷対策を見つけ 出す方法を提案し、その有効性を検証した。

リソースにおけるジョブの競合は納期遅延問題の解決 を難しくしているものの、CSMにより手順をふんで処理す れは、自らの意思を反映してより最適解に近づいた解を得 ることができることを示した

今後の課題としては、
（1）クリティカルパスの全体像をわかりやすく表示する 方法

（2）負荷対策の候補をわかりやすく表示する方法 などがある。

(平成 12 年 5 月 24 日受付, 同 12 年 12 月 21 日再受付)

\section{文 献}

(1) K.Mesghouni, ed. : "Evolution Programs for JobShop Scheduling”, Proc.IEEE Int Conf Syst Man Cybern.(USA) Vol.1, 720-725 (1997)

(2) D.Montana, "Introduction to the Special Issue: Evolutionary Algorithms for Scheduling", Evol. Conput (USA) 6[1] v-ix (1998)

（3）杉原弘章ら：“リソース競合問題を考虑したジョブシ ヨップスケジューリング方式の提案とその実証”, 電 気学会論文誌、Vol.118-D, No.1, 2001

(4) D.Golenko-Ginzburg, ed. "A Heuristic for Network Project Scheduling with Random activity Duration Depending on the Resource Allocation", Int. J. Prod. Econ. 55[2]， 149-162, (1998)

（5） 小野功ら:“クリティカルパスの多样性に着目したジョブシ ヨップスケジューリングの進化的解法”、知的システムシン ポジウム資料、25th、7-12 (1998)

(6) D. Bradbury "Using the Theory of Constraints to Bring Projects in on time", Int Conf Proc Am Prod Invent Control Soc(USA) 39th 161-162 (1996)

(7) V.D.Wiley, ed.: "Optimization Analysis for Design and Planning of Multi-Project Programs", Eur J Oper Res, 107(2), 492-506 (1998)

（8）浜屋毅他: “ジョブショップ生産における負荷計画とスケジ ユーリングの統合”、精密工学会中国四国支部・九州支部 共催学術講演会講演論文集, 61-62 (1996)

杉原弘章（正員）1965 年大阪大学基礎工学部電気

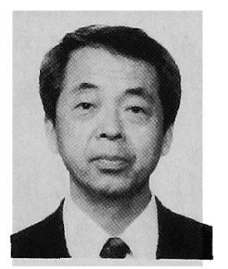
工学科卒業。1967 年東京大学大学院工 学系研究科修士課程電気工学専攻修了。 同年三菱電機株式会社入社。鉄鋼圧延 プラント、食品製造ライン、自動車部 品製造ライン、自動倉庫などのコンピ ユータ制御システムの開発、金型工程 管理システムの開発などに従事。日本

$M E$ 学会会員。 